\title{
Investigations on Veterinary Folklore in the Lower Euphrates Basin: Folk Beliefs and Practices Applied on Animals
}

\author{
Erhan YÜKSEL ${ }^{*}$, Rahşan ÖZEN² \\ ${ }^{1}$ Sivas Cumburiyet University, Veterinary Faculty, Veteriner History and Deontology Department, 58140, Sivas, Turkey \\ ${ }^{2}$ Furat University, Veterinary Faculty, Veteriner History and Deontology Department, 23119, Elaz:ğ, Turkey
}

\begin{abstract}
This study was aimed at the compilation and introduction to the scientific literature of the folk beliefs on animals in the lower Euphrates basin, a major settlement area of common history, which has been home to several civilizations, and thus, is an area of great significance for folklore. For this purpose, in total 78 persons, residing in the lower Euphrates basin in the Adiyaman, Elazı̆g, Malatya and Şanliurfa provinces and the Nizip district of Gaziantep province were interviewed in person. The findings obtained were assessed using the "content analysis" method. The study revealed that, in the lower Euphrates basin, some animals are considered to bring good luck; some animals are considered to bring bad luck. On the other hand, the findings obtained demonstrated that the dog, owl, and fox are considered to bring good luck and to bring bad luck. Furthermore, it was determined that the placenta of newly parturited animals is either hung on the branch of a fig tree or thrown into the river, in the belief that this would increase the milk yield of lactating animals, and it was settled that "pox bowl" is used against smallpox, mole is used against "mole head" disease, and it was ascertained that the skull of horses, cattle, sheep and goats as well as tortoise shells are hung on the walls of houses and stables, in the belief that this would protect the people and animals from the evil eye. In conclusion, rich folkloric elements related to folk beliefs on animals were observed in the lower Euphrates basin and the beliefs of this region were found to be similar to those maintained in the different regions of Anatolia.
\end{abstract}

Keywords: Lower Euphrates Basin, beliefs, veterinary folklore

\section{Aşağı Fırat Havzasında Veteriner Hekimliği Folkloru Üzerine Araştırmalar: Hayvanlar ile İlgili İnanışlar ve Uygulamalar}

ÖZ

Sonraki nesillere aktarılan değerler olan halk inanışları içerisinde, insanoğlunun hayatında ayrılmaz bir parça olan hayvanlar önemli yer tutmakta, aynı zamanda bu inanışlar veteriner hekimliği folklorunun da önemli bir kısmını oluşturmaktadır. Bu araştırmada, bilinen tarihin önemli yerleşim merkezlerinin başında gelen ve halk bilimi açısından büyük önem taşıyan Aşağı Fırat Havzasında, hayvanlar ile ilgili inanışların derlenerek literatüre kazandırılması amaçlandı. Bu amaçla Aşağı Fırat Havzasında yer alan Adıyaman, Elazı̆̆ Malatya, Şanlıurfa illeri ile Gaziantep’in Nizip ilçesinde toplam 78 kişiyle yüz yüze görüşme yapıldı. Elde edilen bulgular "i̧crike analiž̨" yöntemiyle değerlendirildi. Çalışmada, Aşağı Fırat Havzasında horoz, güvercin, koyun, leylek ve kır atın uğurlu; keçi, kedi, alaca sığır, siyah katır, eşek ve tavşanın uğursuz; köpek, baykuş ve tilkinin de uğurlu veya uğursuz hayvanlar olarak kabul edildiği saptandı. Ayrıca, yeni doğum yapan hayvanların eşinin (plasenta), hayvanın sütünün bol olacağı inancıyla incir ağacına asıldığı veya aynı beklentiyle akarsuya atıldığı; çiçek hastalığına karşı "çiçek tası" kullanıldı̆̆ı, "kösnü başı" hastalığında köstebek kullanıldığı; nazardan korunmak için ev ve ahırlara, at, büyükbaş ve küçükbaş hayvanların kafatası ile kaplumbağa kabuğunun asıldığ1 şeklinde bulgulara ulaşıldı. Sonuç olarak, Aşağı Fırat Havzasında, hayvanlarla ilgili inanışlar açısından zengin folklorik uygulamalara rastlandığ1 ve yörede saptanan inanışların birçoğunun Anadolu'nun farklı bölgelerindekilere benzer olduğu saptanmıştır.

Anahtar kelimeler: Aşağı Fırat Havzası, inanışlar, veteriner hekimliği folkloru

To cite this article: Yülesel E. Özen R. Investigations on Veterinary Folklore in the Lower Euphrates Basin: Folk Beliefs and Practices Applied on Animals. Kocatepe Vet J. (2021) 14(1):91-100

Submission: 16.12.2020 Accepted: 14.02.2021 Published Online: 24.02 .2021

ORCID ID; EY: 0000-0002-0735-0375 RÖ: 0000-0001-5788-0289

*Corresponding author e-mail: erhanyukcell@hotmail.com 


\section{GİRİş}

Folklor, halkın geleneğe bağlı maddi ve manevi kültürünü kendine özgü metotlarla derleyen, araştıran, sınıflandıran, çözümleyen ve halk kültürü üzerine değerlendirmeler yapan bir bilimdir (Ülkütaşır 1972, Ekici 2000, Dundes 2005, Tan 2008). Veteriner hekimliği mesleğinin var olan kendine has gelenek ve görenekleri, çeşitli inançlarına "veteriner bekimliği folkloru" adi verilmektedir (Salman 1948, Dinçer 1967, Dinçer 1980, Doğanay 1982, Boratav 1994). Veteriner hekimliği folklorunun bir parçası olan halk inanışları ait oldukları toplumun kimliğini ve karakteristik özelliğini yansıtmaları nedeniyle Türk halk bilgisi açısından önem taşımaktadır (Dinçer 1967, Dinçer 1976, Dinçer 1980, Doğanay 1982, Artun 1998, Yerlikaya 2002, Özen 2006, Çetin 2007, Sinmez 2011, Özen and Yüksel 2014, Küçükaslan and Uçar 2016, Sinmez and Aslim 2017).

Bilinen tarihi devirlerde Anadolu'ya hâkim olan güçlerin öncelikli yerleşim merkezlerinin başında Fırat Havzası (FH) gelmekte (Yuvalı 1992), adını Firat Nehrinden alan bu coğrafi alan, saha ve mekân bakımından Yukarı, Orta ve Aşağı Firat Havzası olarak üç bölüme ayrılmaktadır. FH tarihi öneme sahip bir bölge olarak tanımlanmakta, bu özelliği nedeniyle de halk bilimi açısından önemsenmektedir (Buran 1992, Karaboran 1992, Yuvalı 1992). Ancak, bölgenin tarihi önemine karşın Doğu Anadolu ve FH folkloru üzerine yapılan araştırmalar sınırlı düzeyde kalmıştır (Toygar 1992). Benzer şekilde, FH kapsaminda veteriner hekimliği ve hayvanciltk özelinde yapılan folklorik araştırmaların (Dinçer 1976, Kutlu 1987, Yerlikaya 2002) sayı ve kapsam açısından yetersizliği, yeni planlanması ve gerçekleştirilmesi gereken araştırmalar için gerekçe olarak ortaya çımaktadır.

$\mathrm{Bu}$ araştırmada Aşağı Fırat Havzası (AFH) folklorunda, hayvanlarla ilgili sözlü bilginin toplanarak literatüre kazandırılması ve bu bilginin tarih boyunca AFH'de yaşamış toplumlarla olan bağlarının saptanması amaçlandı.

\section{MATERYAL ve YÖNTEM}

Çalışmada AFH'de yer alan Adıyaman, Elazı̆̆, Malatya ve Şanliurfa illeri ile Gaziantep'in Nizip ilçesinde yoğun hayvancillk faaliyetlerinin yürütüldüğü ilçe ve köylerde 22 Ekim 2010-29 Aralık 2010 tarihleri arasında 78 kaynak kişi ile yüz yüze görüşme yapıldı. Kaynak kişilerle yapılan yüz yüze görüşmeler esnasında kaynak kişi için bir numara verildi. Elde edilen verilere atfen, kaynak kişilerin gösteriminde kullanılan bu kod numaraları, bulgular bölümünde her bir inanışın sonunda üst simge olarak gösterildi. Elde edilen bulgular içerik analizi yöntemiyle değerlendirildi.

\section{BULGULAR ve TARTIŞMA}

\section{Uğurlu ve Uğursuzluk ile İlgili İnanışlar}

Bir evin çatısına baykuşun konması uğursuzluk olarak kabul edilir1 ${ }^{1-3,}$ 5, 15-18, 26, 34-38, 42, 43, 46-48, 55-61, 65, 69-71, 78 . Baykuş genelde viranelere konduğundan tepesine konduğu yuvanın yikılacağ $1^{35-38,42, ~ 43, ~ 60, ~ 61, ~ 69, ~} 70$ veya bir felâkete uğrayacağ1 düşünülür ${ }^{1}, 5,15-18,26,34-38,42,43,55,71$, 78. Evin çatısında öten baykuşun ise evin fertlerinden birinin öleceğine işaret ettiği kabul edilir15-18, 34, 42, 43, 4648, 60, 61, 65, 69-71, 78. Bu nedenle evlere doğru gelen baykuş korkutularak uzaklaştırllır. Baykuşun getireceği felâketten korunmak için bulgur, mercimek, un ve buğdayın pişirilmesi ile hazırlanan karışım evin etrafina bırakilır ${ }^{69}, 70,78$. Baykuşun felaket getirdiği inancindan dolay1 "evinde baykeus okusun" şeklinde bir beddua da bulunmaktadir ${ }^{15-18}$. Adiyaman ve Şanlıurfa'daki bazı kaynak kişilere göre ise evin çatısına baykuşun konması uğurlu görülür2, 3, 65, 71 . Çatiya konduğu zaman baykuşun Allah'a dua edeceği ve çatısına konduğu eve bereket getireceğine ${ }^{2,} 3$ ve baykuşun müjdeci olduğuna inanilır ${ }^{65,71}$.

Sabah ezanında köpeklerin uluması uğursuzluk olarak kabul ediliri-3, 12-14, 35-38, 42-48, 52, 56-61, 7175. Ezan sirasinda köpeklerin uzun uzun ulumas1 (havlamas1) köpeğin Azrail'i görebildiğ 11-3, 12-14, 35-38, 44, 45, 56-59 ve birinin öleceği inanc1 ile açıklanır 1-3, 12-14, 35-38, 42-48, 52, 56-59, 73-75. Köpekler uluduğunda köpeklere "başından bul" diye bağırılır"2, 43. Köpekler hangi evin önünde ulursa o eve Azrail'in gelmesinin yakın olduğuna inanılır 12-14, 73-75. Böyle durumlarda köpeğe "evin basim yiyecek" denir"12-14. Sabah ezan saatinde şeytanın köpeklerin içerisine girdiği ve bu yüzden köpeklerin sabah ezanında havladıklarına inanılır ${ }^{71}$. Öte yandan Adiyaman ve Malatya'da sabah ezanında köpeklerin ulumasının uğurlu kabul edildiği köyler de bulunmaktadir ${ }^{5-8,}$ 10, 11, 15-18, 46-48. Ezan sirasinda köpeklerin uzun uzun ulumas1 "köpekler sabah ezannda yeryüzüne inen melekleri görür o yüzden havlar" 5-8, 10, 11, 46-48 veya "köpekler sabah ezanında Allah'ı niyaz eder" şeklinde açıklanır ${ }^{15-18}$. Evin bahçesinde köpek beslemek uğursuz kabul edilir ${ }^{51,}{ }^{2}$. Çünkü köpeklerin içerisine üç harfliler (cin) girer51. Köpekler necis kabul edilir ve eve sokulmaz 32, 33, 62. Bu inanış özellikle şafi mezhebinde olanlar için geçerlidir ${ }^{62}$. Bu nedenle, kedi-köpeğin girdiği yerde/evde namaz kılınmaz ${ }^{32-38,}$ 62.

Arabanın veya insanın önünden tavşan geçerse uğursuzluk olacağına inanıllır $5,44,45,51$.

Leylek görülmesi uğurlu sayılır. Leyleği uçarken gören kişinin yolculuk yapacağına inanıllır ${ }^{12-18,}$ 46-48.

Eşeklerin evin önünde veya ahırda çok anırmasının (bağırmasının) felaket habercisi olduğuna inanilır. Hayvanlar anırdığında "bu eşek çok zurlyyor, kesin başımıza bir şey gelecek" diye düşünülür ${ }^{64}$.

Arabanın veya insanın önünden tilki geçmesi uğurlu sayllan bir durumdur ${ }^{5,12-14,42-45,51}$. 
Gece vakti kedilerin ses çıkarmaları uğursuzluk olarak kabul edilir ${ }^{46-48,}$ 50. Siyah kedi görmek uğursuzluk say1lir42, 43, 56-61.

Şavak Aşireti mensupları koyunlarına Çarşamba günleri tuz vermezler ve bugünü uğursuz kabul ederler. Eğer tuz verilirse bütün hayvanların hasta olacağına inanırlar ${ }^{32-34}$.

Avcıların av yolunda tilki görmeleri uğurlu sayılır ${ }^{5,} 44$, $45,60,61$.

Koç katımının Pazar veya Perşembe günü yapılması uğurlu say1lir ${ }^{32,33}$.

Hayvanlar, insanlara gönderilmiş nimet, kısmet olarak kabul edilir ve hayvanlara iyi bakmak ibadet olarak görülür ${ }^{40,41}$.

Hayvanlar otlaklar veya yaylalarda ne zaman güzel yayılırsa yağış olduğu inancı bulunmaktadır. Bu nedenle hayvanların güzel yayılması yağış olacağına işaret olarak kabul edilirro-8.

Kurban kanının alına sürülmesinin uğur getireceğine inanilır ${ }^{31,60,61 .}$

Kuşların yuvasını bozanın yuvasının bozulacağına inanilir ${ }^{31,34,44-48 .}$

Ev halkından biri yolculuğa çıktığında eğer bir süre sonra evdeki horoz öterse yolculuğa çıkan kişinin yolunun açık olacağına inanılır ${ }^{71}$.

Koyun meleğe, keçi ise şeytana benzetilir26, 29, 30 .

Güvercinin mübarek hayvan olduğuna inanılır ve yakın olduğu ya da beslendiği eve bereket getireceğine inan1lir $24,29,56,70,74$

Kır at uğurludur derler ve uğurlu kabul edilir ${ }^{31}$.

Alaca sığır uğursuz kabul edilir ve beslenmesi hoş karşılanmaz ${ }^{31}$.

Kara renkli erkek katırlar alınmaz, çünkü bunların "buylu" (asabi) olduğuna inanılır ${ }^{31}$.

\section{Nazar ile İlgili İnanışlar}

Nazara çok inanilır ve nazar "göz. değmesi" olarak isimlendirilir ${ }^{1}$, 4, 5, 9, 40-43, 46-49, 52, 60, 61, 63, 65. Hayvanlar1 nazardan korumak için boyunlarına mavi nazar boncuğu1, 4, 5, 9, 40-43, 46-48, 52, 60, 61, 63 ile Kuran-1 Kerim'den ayetler ve dualar yaz1lı olan “muska"lar asillir $^{1}$, 5, 9, 40, 41, 46-48, 52, 63. Ayrica kaplumbağa kabuğunun nazara karşı koruyucu olduğuna inanılır, hayvanların boyunlarına ${ }^{65}$, ev ve ahır girişlerine kaplumbağa kabuğu as1lir ${ }^{31,}$ 34, 76-78. Hayvanların boyunlarına asılan kaplumbağa kabuğu içerisine taş konur ve taşların çıkardığı seslerin hayvanları kötülük ve hastalıklardan koruduğuna inanılır ${ }^{65}$. Nazardan korunmak için ev ve ahırların girişlerine at kafasi ${ }^{49}$ ve at nalı26, 49 asılır. Nazara karşı kaplumbağa kabuğu, büyükbaş ya da küçükbaş hayvanların kafatasları ahır girişlerine asılır 46-48, 51. Ayrıca, nazardan korunmak için Kuran-1 Kerim'den İhlas Suresi üç kez okunarak hayvanın yüzüne doğru üflenir ${ }^{69}, 70$.

Koç katımında koçlara nazar değmesin diye kına sürülür ${ }^{31-33}$

\section{Hastalık ve Tedavi ile İlgili İnanış ve Uygulamalar}

Koyunlarda çiçek hastalığında tedavide ve hastalıktan korunmada "çiçek tasi” (Bkz Şekil 1) kullanılır23-25, 27-30. Bakırdan yapılan ve kimilerinin üzerinde Kuran-1 Kerim'den ayetler bulunan ${ }^{23-25}$ çiçek tas1 Hicaz'dan (Suudi Arabistan) getirilirr6- 68. Çiçek tas1 içerisine su alınır ve hayvanlara tas içerisindeki su serpilir ${ }^{23,27-30,39 .}$ Su serpilirken çadırın kapısının önünde durulur ve tastaki su dişarıya çıkarılan hayvanlara serpilir ${ }^{23-25}$. Bir başka uygulamada ise çiçek tası içerisine alınan herhangi bir ziyaretten (yatır) getirilen toprak ile karıştırılan su hayvanlara serpilir. Çiçek tası güneş görmemelidir. Çiçek tasıyla su serpilmesi ya gün (güneş) doğmadan önce ya da gün battıktan sonra yapılmalıdır. Hayvanlar siyah bir kil çadırın altına toplanır ve burada tüfek sik1lıp ürkütülerek tedavi edilmeye çalışılır ${ }^{35-38}$.

Adiyaman'daki hasta hayvanlar Çoban Dede Köyündeki "Coban Dede" adlı ziyarete götürülür ve hayvanların bu ziyarette şifa bulacağına inanılır. Çoban dedenin mezarından alınan toprak ahırın tavanına asılırsa, o ahıra artık kene ve hastalığın girmeyeceğine inanılır ${ }^{19-22}$ (Bkz Şekil 2).

İnsanlar, “kösnï’ (köstebek) öldürdüklerinde vücutlarında irinli yaralar oluşur. Bu yaralara “kösnü baş»" adı verilir. Hastalığın tedavisi için köstebek yakalanıp öldürülür. Derisi ve iç organları çıkarılan köstebek yara üzerine bağlanır ve yaranın iltihabını iyileştirir ${ }^{56-59}$.

Kurbağaya dokunulursa vücutta siğil ç1kar12-14, 31, 50. Hayvanları hastalıklardan korumak için yaylanın gidebildiği kadar üst kısımlarına gidilmeye çalışılır ve zirveye yakın yerlerin hastalıktan korunmak için en ideal yerler olduğuna inanılir ${ }^{31}$.

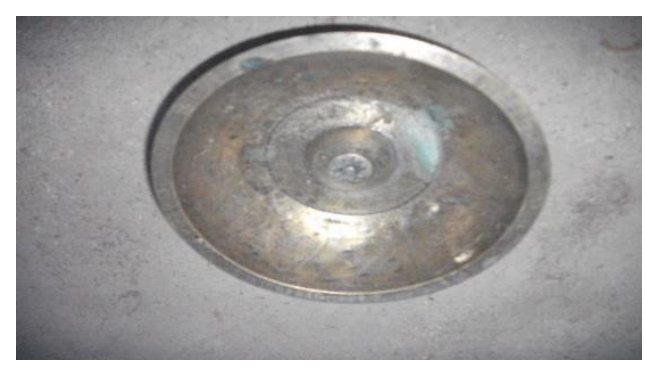

Şekil 1. Çiçek tası

Figure 1. Pox bowl 


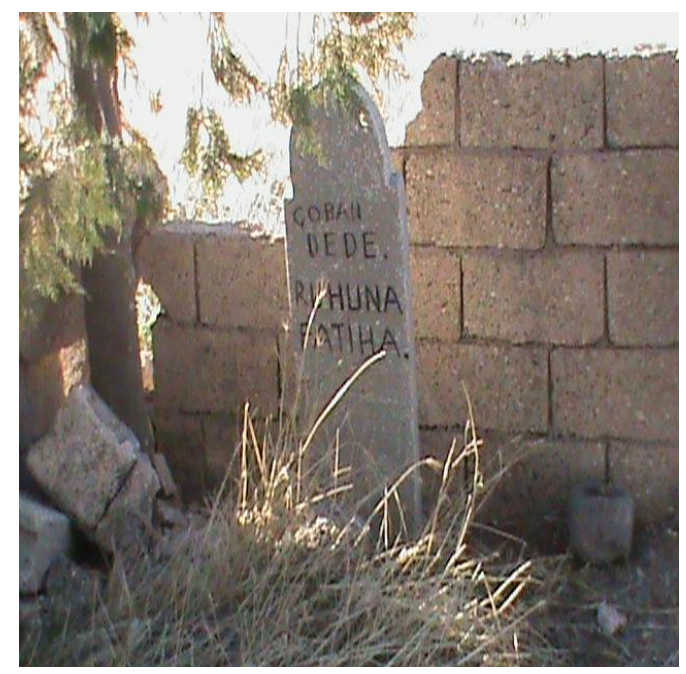

Şekil 2. Adıaman'daki "Coban Dede" ziyareti

Figure 2. "Coban Dede" holy visiting place in the Adiyaman-Turkey

\section{Yer, Su, Ev ve Ağaç İyeleri ile İlgili İnanışlar}

Yeni doğum yapan hayvanların eşi düştüğü zaman, düşen eş alınarak götürülüp bir akarsuya atıllır. Bu uygulama ile doğum yapan hayvanın sütünün akarsu gibi bol olacağına inanıllır ${ }^{53,54,56-61}$. Düşen eş bir incir ağacının üzerine atıldığında da yeni doğan hayvanın incir gibi bol sütlü olacağı düşünülür2-8, 10, 15-18.

Salgin hastaliklarda, ölen hayvanlardan birinin ayağ 1 kesilerek bir ağaç dalına asılırsa, hastalık ve ölümün sürüden uzak olacağına inanil11 ${ }^{73-75}$.

Herhangi bir evde süte katılacak maya yere dökülürse komşu evler o eve maya vermezler. Maya verirlerse başlarına bir uğursuzluk veya hayvanlarının başına hastalık geleceğini düşünürler ${ }^{32,33}$.

\section{Dini İnanışlar}

Bir mutfak kabina fare girerse mutfak kabı artik haram kabul edilir ve kullanilmaz ${ }^{24,}$, 25, 31-34, 42, 43, 46-48, 69, 70, 76- 78. Tekrar kullanılması için mutfak kabı ile bir çeşmeye gidilmesi, su doldurulurken İhlâs Suresinin üç kez okunması ve kabın içerisindeki suyun boşaltılması gereklidir. Farenin temas ettiği kabın tekrar kullanılabilmesi için yedi31-34, 46-48, 69, 70, 76-78 veya $40 \mathrm{kez}^{15-18,}, 42-45,69,70$ temiz su ile doldurulup boşaltılması gerekmektedir ${ }^{15-18,31-34, ~ 42-45, ~ 46-48, ~ 69-70, ~ 76-78 . ~}$ Kuyulara fare düşerse o kuyudaki suyun tekrar kullanılabilmesi için köyün inanç sistemi açısından önde geleni (sofisi veya imami) kuyudan $300 \mathrm{kez}$ su çeker ve yere döker ${ }^{65}, 73-75$. Daha sonra en son çektiği sudan bir tas içer ve "ben içtim artık helaldir" der"65. Eğer kuyuya düşen fare canlı ise kuyudan kova ile $150 \mathrm{kez}$ su çekilir, yere dökülür ve kuyudan her kova su çekişte Kelime-i Şahadet getirilirr ${ }^{73-75}$.

\section{Diğer İnanışlar}

Büyükbaş hayvanlarda çiftleştirmeden sonra dişi hayvanın üzerine bir erkek binerse hayvanin yavrusunun erkek, eğer bir kadın binerse dişi olacağına inanıllır ${ }^{15-18}$.

\section{TARTIŞMA}

Elde edilen bulgular 1şı̆̆ında AFH'de varliğını sürdürdüğü tespit edilen hayvanlar ile ilgili inanışların zengin bir içeriğe sahip olduğu söylenebilir.

Gerek ürünlerinden gerekse güçlerinden faydalanılan hayvanlar bu özelliklerinin yanı sıra manevi olarak da baz1 özelliklere sahiptiler. Hayvanlar, insanların günlük hayatlarında yer aldıkları gibi, inanç sistemleri içinde de oldukça önemli görevler üstlenmektedirler. Kurt, boğa, koç, teke, kartal veya yırtıcı kuşlar gibi hayvanların totemizm döneminde Orta Asya kavimlerinin çoğunda kutsal saydıkları bildirilmektedir (İnan 2000). AFH'de ise köpek, baykuş ve tilkinin hem uğurlu hem uğursuz olarak kabul edildiği, horoz, güvercin, koyun, leylek ve kır atın uğurlu; keçi, kedi, alaca sığır, siyah katır, eşek ve tavşanın uğursuz kabul edildiği bulgularına ulaşıldı. Yolculuk esnasında tilkinin araç ve şahısların önünden geçmesinin uğurlu, tavşanın ise uğursuz olduğu bulguları önceki araştırmalarda bildirilmiştir (Roux 2005, Kalafat 2012, Özen and Yüksel 2014, Sinmez and Aslım 2017). Bununla birlikte literatürde tavşanla ilgili olarak yakutlarda kuraklığın habercisi olduğu (Roux 2005, Ergun 2011), Tatar Türklerinin ise tavşan yllında kitlık olacağına inandıkları (Tavkul 2007, Ergun 2011); tilki ile ilgili olarak da Altaylar ve Yakutlarda ata simgesi olduğu, Eski Türklerde (Kırgizlar, Kazaklar ve Yakutlar) ve Moğollarda kutsal bir hayvan olarak kabul gördüğü (Ögel 1993, Araz 1995, Duvarc1 2005, Yıldız 2011), yine Bektaşilerin, tilkinin Hızır olabileceği inanc1 nedeniyle uğurlu bir hayvan olarak kabul ettikleri bildirilmektedir (Kilıç 2000, Mollaibrahimoğlu 2008). Buradan hareketle AFH'de varlığı tespit edilen tilki ve tavşan ile ilgili inanışların kökenlerinin Orta Asya'ya ve Bektaşi kültürüne dayandığı, tavşan ile ilgili olarak Kayseri (Özen and Yüksel 2014) ve Diyarbakır (Küçükaslan and Uçar 2016) özelinde elde edilen verilerin benzer olduğu 
söylenebilir. Öte yandan baykuş, köpek ve tilki ile ilgili elde edilen sonuçlara göre, bu hayvanların hem uğurlu hem de uğursuz olarak kabul edilmesinin Anadolu'da yaşamış farklı kültürlerin izlerinin bir göstergesi olduğu ileri sürülebilir. "Belli kimselerde bulunduğuna inamulan; insanlara, özellikle cocuklara, evcil bayvanlara, eve, mala mülke, hatta cansiz nesnelere de zarar veren, bakıştaki çarpıcı ve öldürü̈ü gü̈s" (Anonim 1998) olarak tanımlanan nazar ile ilgili olarak Anadolu'da hastalıkların bir kısmının "nazar değmesi"nden ileri geldiği ve nazardan korunmak için mavi boncuk, muska, at ve eşek nalı, kaplumbağa kabuğu, köpek ve at kafası gibi nesnelerin kullanıldığ bildirilmiştir (Dinçer 1967, Araz 1991, Arslan 1998, Yerlikaya 2002, Kurum 2008, Mollaibrahimoğlu 2008, Sinmez 2011, Özen ve Yüksel 2014, Küçükaslan and Uçar, 2016, Sinmez and Aslim 2017). AFH'de "göz değmesi" olarak isimlendirilen nazar inancinın yaygin olduğu ve nazardan korunmak için hayvanların boyunlarına mavi nazar boncuğu, muska ve içerisine taş koyulan kaplumbağa kabuğunun asıldığ1, ev ve ahırlara at kafası, kaplumbağa kabuğu, büyükbaş ya da küçükbaş hayvanların kafataslarının asıldığı ve İhlas Suresinin üç kez okunarak hayvanların yüzüne doğru üfürüldüğü bulgularına ulaşıldı. Buradan hareketle nazardan korunmak ve "göz. değmesi" olarak adlandır1lan hastalıklarda yapılan uygulamaların dinî-sihrî tedavi yöntemlerine örnek olarak gösterilebileceği söylenilir. Öte yandan hayvanlarin boyunlarina asilan kaplumbağa kabuğu içerisine taş koyulmasının, taşların çıkardığ1 seslerin hayvanları kötülük ve hastalıklardan koruduğuna yine ölen hayvanlardan birinin ayağı kesilerek bir ağaç dalına asılması uygulamalarının Şamanizm'de var olan kötü ruhların korkutularak uzaklaştırılması uygulamalarının (Erk 1978) devamı niteliğinde olduğu ileri sürülebilir.

Türk toplumlannnda su, yaşam ve bereket kaynağı olarak kabul edilir ve Türk inanç sisteminde "su" iyeleri kutsaldır (Araz 1991, Akman 2002, Kalafat 1990). Akarsular, halk inanışları çerçevesinde kutsal sayılan ve adakta bulunulan unsurlardır (Kalafat 2012). Anadolu'da doğum sonrası yapilan uygulamalara ilişkin olarak plasentanın bir ağaç dalına asilmas1 (Araz 1991, Sinmez 2011) veya suya atılmas1 (Özen and Yüksel 2014) ayrıca, doğum sonrası sağıllan ilk sütün de suya atılmasiyla (Araz 991, Özen and Yüksel 2014) ilgili inanışların varlığı daha önce yapilmış çalışmalarda bildirilmiştir. Bununla birlikte AFH'de yeni doğum yapan hayvanların düşen eşinin sütünün bol olması için bir incir ağacinın üzerine asıldığ1 ve yine yeni doğum yapmış hayvanların eşlerinin aynı beklenti ile akarsulara atıldığı tespit edildi. Altay inanışlarına göre evcil hayvanları yaratan ve onlara bereket verenin yer su iyeleri olduğu ve Türk toplumlarında suyun kutsal kabul edildiği (İnan 1998, Araz 1999) dikkate alındığında AFH'de doğum sonrasi yapılan uygulamaların kutsallik ve bereket temelli olan Eski Türk inanışlarının izlerini taşıdığ söylenebilir.
Türklerde barınılan alanların koruyucu bir iyesi olduğu ki buna "yer iyesi" ad1 verildiği ve iyenin memnun edilmesi ve kızdırılmaması gerektiğine inanıldığı bilinmektedir (Kalafat 1990, Araz 1991). Bununla ilgili olarak Erzurum'da akşamları ev dışına maya; Ağrı, Elazığ ve Diyarbakır'da da ateş, ekşi hamur, tuz, iplik, Kayseri'de yün tarağı gibi nesnelerin verilmemesi aksi halde evin bereketinin kaçacağ1 (Kalafat 1990, Özen and Yüksel 2014) şeklindeki inanışlar bulunmaktadır. Buradan hareketle AFH'de tespit edilen mayanın komşu eve verilmemesi şeklindeki inanışın ev iyesi kızdıracak davranıştan kaçınılması ve iyeyi memnun etme ile ilişkilendirilebileceği söylenebilir.

AFH'de elde edilen bulgular arasinda yer alan Adıyaman'daki hasta hayvanların Çoban Dede Köyündeki "Coban Dede" adlı ziyarete götürülmesi, Çoban dedenin mezarından alınan toprak ahırın tavanına asılması uygulamalarının günümüzde hala varllğı devam eden dini-sihri tedavileri (Erk 1978) için örnek teşkil ettiği söylenebilir.

Gebelik teşhisi ve yeni doğacak yavrunun cinsiyeti ile ilgili olarak, Eski Mısırda çeşitli uygulamaların var olduğu bilinmektedir (Ghalıoungu1 et al. 1963). Bununla birlikte hayvanlarda doğacak yavruların cinsiyeti ile ilgili olarak Arapça bir yazma eserde "Erkele yauru istiyorsan să̆ testisi bağlamalisın" (Özen 1999), ve yine bir başka Arapça yazma eserde "kısrağın önce să memesinden süt gelirse yauru erkek, ĕger sol memeden gelirse dişi olur" (Yiğit 2011) bilgileri yer almaktadır. Doğacak yavrunun cinsiyeti ile ilgili olarak kuzuların erkek doğması için koçların üstüne erkek çocuğu, dişi kuzu doğması için kız çocuğu bindirildiği bulguları İç Anadolu Bölgesinde yapılan folklorik bir araştırmanın sonuçları arasında yer almışır (Sinmez and Aslım 2017). Buradan hareketle AFH'de elde edilen büyükbaş hayvanlarda çiftleştirmeden sonra dişi hayvanın üzerine bir erkek binerse hayvanın yavrusunun erkek, eğer bir kadın binerse dişi olacağ inancının Anadolu'daki yaygın inanışlardan biri olduğu bu ve benzeri uygulamaların kökeninin Eski Mısır Uygarllğını ve yazma eserleri işaret ettiği ileri sürülebilir.

Ünver (1948), Çiçek Hastalığının çok eski tarihlerden beri bilindiğini, Eski Hint ve Çin Uygarlıklarında çiçek hastalığıyla oluşan kabarcıkların kurumuş kabuklarının burun içine sokularak aşılama yapıldığını bildirmiştir. Dinçer (1967), çiçek hastalığının tedavisinde ocak metodunun kullanıldı̆̆ını, tedavide çiçek değneği ile koyunlara dokunulduğu ve çiçek hastalığ 1 için Türklerde aşılama yönteminin kullanıldığını, Doğanay (1982) ise çiçek hastalığının sağaltımının "çiçekçı" adı verilen ocaklar tarafindan aşılama ile yapıldı̆̆ını bildirmiştir. Yerlikaya (2002), çiçek hastalığının tedavisinde büyüsel bir güç kaynağ1 olduğuna inanılan "cicek tasi" ve "ciçek çubuğu" nun kullanildığını ayrica yine aşılama uygulamalarının var olduğunu bildirmiştir. Sinmez (2011), çiçek hastalığının tedavisinde "çiçek tasi"nın önemli yer tuttuğunu ve aşılama tekniğinin uygulandığını bildirmiştir. Çiçek hastalığı ile ilgili olarak AFH'de elde edilen "çicek tası" 
kullanımının Yerlikaya (2002) ve Sinmez (2011)'in bulgularıly benzer olduğu söylenebilir. Öte yandan, AFH'de çiçek hastalığının tedavisinde hayvanların çadır altına toplanıp silah sikılarak korkutulması şeklindeki uygulamanın Türklerde Şamanizm'den kalma bir gelenek olan ve hastalıkların nedeni olduğu düşünülen kötü ruhları uzaklaştırmak için şamanın davul çalarak gürültü yapması (Erk 1978) geleneğinin devam ettiğinin bir göstergesi olduğu ileri sürülebilir. Köstebeğin Eski Hint Uygarllğında sağlık dağıtan bir hayvan olarak bilindiği, eti, kanı, baş ve diş organları ya da bunların külleri hatta yuvasının topraklarının Eski Hint, Yunan ve Roma Uygarlıklarından beri kullanıldığı literatür bilgileri arasında yer almaktadır (Sigerist 1961, Dinçer 1967). Ege Bölgesinde "köstebek" adı verilen hastalı̆̆ın tedavisinde köstebek etinin yedirildiği bildirilmiştir (Arslan 1998). Çalışma sonuçlarına göre, "kör fare" olarak adlandırılan köstebeğin ön iki dişinin meme hastalıklarının tedavisinde; derisi ve iç organlarının ise "kösnü başı" adı verilen beşeri hastalığın tedavisinde kullanıldığ tespit edildi. Bu bulgular Eski Hint, Yunan ve Roma Uygarlıklarından beri uygulanan benzer yöntemlerin varllğına delil sayılabilir.

Sonuç olarak, Aşağı Fırat Havzasının veteriner hekimliği folkloru açısından zengin folklorik ögeler barındırdığı; varlığı tespit edilen inanışların eski uygarlıklara kadar uzandığı söylenebilir. Bununla birlikte yörede saptanan ve inançların Anadolu'nun farklı bölgelerindekilere benzer olduğu, farklılıkların ise zaman içerisinde yeni ekleme ve değişmelerden kaynaklandığg ileri sürülebilir.

Tez Bilgileri: İlk isim yazarın "Aşağı Fırat Havzasında Veteriner Hekimliği Folkloru Üzerine Araştırmalar" başlıklı Doktora Tezi’nden özetlemiştir.

Açıklama: VII. Lokman Hekim Tip Tarihi ve Folklorik Tip Günleri (2013) özet bildiri olarak sunulmuştur.

Çıkar Çatışması: Yazarlar, çıkar çatışması olmadığını beyan eder.

\section{KAYNAKLAR}

Akman E. Türk ve dünya kültüründeki su kültü üzerine düşünceler. Kastamonu Eğitim Dergisi. 2020; 10 (1):1-10.

Anonim. Türkçe Sözlük. Cilt-2, 9. Baskı. Türk Tarih Kurumu Basımevi, Ankara. 1998; 635.

Araz R. Harput’ta Eski Türk İnançları ve Halk Hekimliği. Atatürk Kültür, Dil ve Tarih Yüksek Kurumu Yayınları, No:108, Levent Ofset Matbaacilık, Ankara. 1991.

Arslan ES. Ege Bölgesi Folklorunda Veteriner Hekimliği ve Hayvancılık Üzerine Araşıtırmalar. Doktora Tezi, Ankara: Ankara Üniversitesi, Sağlık Bilimleri Enstitüsü, Ankara, 1998.

Artun E. Tekirdağ'da batıl inanışlar. Tekirdağ Halk Kültürü Araştırmaları 1. 1998; 66-83.
Boratav PN. Türk halkbilimi II / 100 Soruda Türk Folkloru (İnanışlar, Töre ve Törenler, Oyunlar). Gerçek Yayınevi, İstanbul.1994; 122

Buran A. Fırat Havzasında Eski Türk Gelenek ve Görenekleri. Firat Üniversitesi Firat Havzası Folklor ve Etnografya Sempozyumu (24-27 Ekim 1985), Elazığ. 1992; 33-44.

Çetin ÇZ. Tatar Türklerinde mitolojik varlıklarla ilgili mitler ve inanışlar (iyeler ve yaratıklar). Bilig. 2007; 43:1-32.

Dinçer F. Türk Folklorunda Veteriner Hekimliği Üzerine Araştırmalar. Doktora Tezi, Ankara Üniversitesi Veteriner Fakültesi Yayınları: 214, Ankara, 1967.

Dinçer F. Türk Folklorunda Veteriner Hekimlik (Beş Doğu İlimizde Yeni Örnekleriyle). I. Ulusal Türk Folklor Kongresi Bildirileri, Cilt 4, DSİ Basım ve Foto Film İşletme Müdürlüğü, Ankara, 1976.

Dinçer F. A report on the Folklore Activites and Folk Veteriner Medicine in Turkey. Ankara Üniversitesi Veteriner Fakültesi Dergisi. 1980; 18 (2): 237-45.

Doğanay S. Afyon Folklorunda Veteriner Hekimlik Araștırma ve İncelemeleri. II. Milletlerarası Türk Folklor Bildileri Cilt 4, G. Ü. Basın-Yayın Yüksekokul. Basımevi, Ankara, 1982; 131-151.

Dundes A. Aydın G (Çeviren). Folklor Nedir? Milli Folklor Dergisi. 2005; 9 (65): 127-130.

Duvarc1 A. Türklerde tabiat üstü varlıklar ve bunlarla ilgili kabuller, inanmalar, uygulamalar. Bilig. 2005; 32:125-44.

Ekici M. Halk, Halk Bilimi ve Halk Bilgisi Üzerine Bir Deneme. Milli Folklor Dergisi. 2000; 6 (45): 2-9.

Ergun P. Alevilik -Bektaşilikteki tavşan inancının mitolojik kökenleri üzerine. Türk Kültürü ve Hacı Bektaşı Veli Araştırma Dergisi. 2011; 60: 281- 312.

Erk N. Veteriner Tarihi. 2. Baskı, Ankara Üniversitesi Basımevi, Ankara, 1978.

Ghaliounguı P, Khalıl SH, Ammar AR. On an Ancient Egyptian Method of Diagnosing Pregnancy and Determining Foetal Sex. Med. Hist. 1963; 7 (3): 241 248.

İnan A. Türklerde Su Kültü ile İlgili Gelenekler. Makaleler İncelemeler, Cilt-I, Türk Tarih Kurumu Basımevi, Ankara, 1998.

İnan A. Tarihte ve Bugün Şamanizm: Materyal ve Araştırmalar. Türk Tarih Kurumu Basımevi, Ankara, 2000.

Kalafat Y. Doğu Anadolu'da Eski Türk İnançlarının İzleri. Türk Kültürünü Araştırma Enstitüsü Yayınları, Ankara, 1990; $50,56,77,97,98$.

Kalafat Y. Türk Halk İnançlarında Tabu. Berikan Yayınevi, Ankara, 2012; 68, 122, 123.

Karaboran H. Folklor Açısından Doğu Anadolu Bölgesinde Köy Araştırmalarının Önemi. Fırat Üniversitesi Fırat Havzası Folklor ve Etnografya Sempozyumu (24-27 Ekim 1985), Elazığ, 1992; 143-155.

Kılıç A. Isparta yöresi halk inançları. Uluslararası Anadolu İnançlar1 Kongresi. 23-28 Ekim, Ürgüp (Nevşehir)Türkiye, 2000. 
Kurum U. Düziçi'nde Halk Hekimliği. Doktora Tezi, Niğde Üniversitesi Sosyal Bilimleri Enstitüsü, Niğde, 2008.

Kutlu MM. Şavaklı Türkmenlerde Göçer Hayvancilık. Sevinç Matbaas1, Ankara, 1987.

Küçükaslan Ö, Uçar M. Diyarbakır Folklorunda Hayvanlar Üzerine Bir Araştırma. Eurasian Journal of Veterinary Sciences. 2016; 32 (4): 220-228.

Mollaibrahimoğlu Ç. Anadolu Halk Kültüründe Hayvanlar Etrafinda Oluşan İnanç ve Pratikler. Yüksek Lisans Tezi, Karadeniz Teknik Üniv. Sosyal Bilimler Enstitüsü Türk Dili ve Edebiyatı Programı, Trabzon-Türkiye, 2008.

Ögel B. Türk Mitoloji I. Cilt. İkinci Baskı, TTK Basımevi, Ankara. 1993; 560.

Özen A. Millî Kütüphanedeki Yazma Baytarnameler Üzerinde Tarihsel İncelemeler. Doktora Tezi, Ankara Üniversitesi Sağlık Bilimleri Enstitüsü, Ankara: 1999.

Özen R. Kayseri Folklorunda Evcil Hayvanlarla İlgili Atasözleri. Erciyes Üniversitesi Veteriner Fakültesi Dergisi. 2006; 3 (2): 177-121.

Özen R, Yüksel E. Kayseri Folklorunda Hayvanlar İle İlgili İnanışlar Üzerine Bir Değerlendirme. Erciyes Üniv Vet Fak Derg. 2014; 11 (1): 23-28.

Roux JP. Orta Asya'da Kutsal Bitkiler ve Hayvanlar. Kabalc1 Yayınevi, İstanbul. 2005; 76, 80.

Salman M. Halk Hekimliği ve Halk Veterinerliği. Milli Kültür Araştırmaları: VIII, Ulus Basımevi, Ankara. 1948; 35-66.

Sigerist HE. A History of Medicine Volume II Early Greek, Hindu and Persian Medicine. Oxford Universty Press, Newyork. 1961.

Sinmez ÇÇ. Bozlak Kültüründe Folklorik Veteriner Hekimliği ve Hayvancilık Üzerine Araştırma. Doktora Tezi, Selçuk Üniversitesi Sağlık Bilimleri Enstitüsü, Konya: 2011.
Simez ÇÇ, Aslım G. İç Anadolu Bölgesindeki Hayvanlarla İlgili İnanış ve Uygulamalar Üzerine Bir Değerlendirme. Bilig, 2017; 81: 205- 232

Tan N. Folklor (Halk Bilimi) Genel Bilgiler. Genişletilmiş 7. Bask1, Özal Matbaas1, İstanbul. 2008.

Tavkul U. Kültürel etkileşim açısından On İki Hayvanlı Türk Takviminin yayılışı. Modern Türklük Araştırmaları Dergisi. 2007; 4(1): 25-45.

Ülkütaşır MŞ. Cumhuriyet'le Birlikte Türkiye'de Folklor ve Etnografya Çalışmaları. Başbakanlık Kültür Müsteşarlığı Cumhuriyet 50. Yıldönümü Yayınları: 1, Başbakanlık Basımevi, Ankara. 1972.

Ünver AS. Türkiye'de Çiçek Aşısı ve Tarihi. İstanbul Üniversitesi Tıp Tarihi Enstitüsü No: 38, İsmail Akgün Matbaas1, İstanbul. 1948

Toygar K Türkiye Folklorunun Derleme Öncelikleri İçerisinde "Fırat Havzas1 Folkloru"nun Önemi. Firat Üniversitesi Firat Havzas1 Folklor ve Etnografya Sempozyumu (24-27 Ekim 1985), Elazığ, 1992; 357-363.

Yerlikaya H. Elazığ ve Çevresinde Hayvan Hastalıklarında Halk Hekimliği Üzerine Araştırmalar. Kafkas Üniversitesi Veteriner Fakültesi Dergisi. 2002; 8 (2): 131-138.

Yıldız ŞN. Türk Halk Anlatılarında Hayvan Motifleri. Yüksek Lisans Tezi. Fırat Üniv. Sosyal Bilimler Enstitüsü Türk Dili ve Edebiyatı Programı. Elazığ-Türkiye, 2011.

Yiğit A. "İlm-i Fürusiyet" İsimli Baytarnamenin Veteriner Hekimliği Tarihi, At Yetiştiriciliği ve Hastalıkları Açısından Değerlendirilmesi. Doktora Tezi, Selçuk Üniversitesi Sağlık Bilimleri Enstitüsü, Konya: 2011.

Yuvalı A. Fırat Havzası'nın Türk Tarihindeki Yeri. Firat Üniversitesi Firat Havzasi Folklor ve Etnografya Sempozyumu (24-27 Ekim 1985), Elazığ, 1992; 389-398. 


\section{Kaynak Kişi Listesi}

\begin{tabular}{|c|c|c|c|c|c|c|c|}
\hline $\begin{array}{l}\text { Kod } \\
\text { No. }\end{array}$ & Ad1-Soyad1 & $\begin{array}{l}\text { Doğum } \\
\text { Tarihi }\end{array}$ & Meslek & Aşiret & $\begin{array}{l}\text { Görüşme } \\
\text { Tarihi }\end{array}$ & Köy /Belde & İl-İlçe \\
\hline 1 & Seydi DİLEK & 1968 & Vet. Hek. & - & 06.11 .2010 & Geçitli Köyü & Besni-Adiyaman \\
\hline 2 & Vakkas SADIK & 1933 & Çiftçi & - & 06.11 .2010 & Karagüveç Köyü & Besni-Adiyaman \\
\hline 3 & Mustafa SADIK & 1956 & Esnaf & - & 06.11 .2010 & Karagüveç Köyü & Besni-Adiyaman \\
\hline 4 & Vakkas TÜRK & 1945 & Çiftçi & - & 06.11 .2010 & Kidiş Köyü & Besni-Adiyaman \\
\hline 5 & $\begin{array}{l}\text { Vakkas } \\
\text { GÜNGÖR }\end{array}$ & 1965 & Çiftçi & - & 06.11 .2010 & Balmir Köyü & Besni-Adiyaman \\
\hline 6 & $\begin{array}{l}\text { Osman } \\
\text { ÖZDEMİ }\end{array}$ & 1956 & Çiftçi & - & 07.11 .2010 & Tek Ağaç Köyü & Besni-Adiyaman \\
\hline 7 & Şükrü TANIR & 1973 & Çiftçi & - & 07.11 .2010 & Tek Ağaç Köyü & Besni-Adiyaman \\
\hline 8 & Osman BÖRTA & 1952 & Çiftçi & - & 07.11 .2010 & Tek Ağaç Köyü & Besni-Adiyaman \\
\hline 9 & Hasan ASLAN & 1973 & Çiftçi & - & 10.11 .2010 & Ortanca Köyü & Kâhta-Adıyaman \\
\hline 10 & Mustafa KAMER & 1960 & Çiftçi & - & 10.11 .2010 & Tuğlu Köyü & Kâhta-Adıyaman \\
\hline 11 & İbrahim DOĞRU & 1952 & Çiftçi & - & 11.11 .2010 & Tekayaz Köyü & Kâhta-Adıyaman \\
\hline 12 & $\begin{array}{l}\text { Muhammed } \\
\text { ALTUĞ }\end{array}$ & 1929 & Çiftçi & - & 12.11 .2010 & Şahintepe Köyü & Kâhta-Adıyaman \\
\hline 13 & Mehmet DOĞAN & 1941 & Çiftçi & - & 12.11 .2010 & Şahintepe Köyü & Kâhta-Adıyaman \\
\hline 14 & Ömer TOSUN & 1934 & Çiftçi & - & 12.11 .2010 & Şahintepe Köyü & Kâhta-Adıyaman \\
\hline 15 & Mehmet ASLAN & 1943 & Çiftçi & - & 13.11 .2010 & Bozik Köyü & Merkez Adıyaman \\
\hline 16 & Hac1 Halit ASLAN & 1944 & Çiftçi & - & 13.11 .2010 & Bozik Köyü & Merkez Adıyaman \\
\hline 17 & Yusuf ASLAN & 1958 & Şöför & - & 13.11 .2010 & Bozik Köyü & Merkez Adiyaman \\
\hline 18 & Mehmet GÜLER & 1936 & Çiftçi & - & 13.11 .2010 & Bozik Köyü & Merkez Adıyaman \\
\hline 19 & $\begin{array}{l}\text { Mustafa } \\
\text { DIŞKIRAN }\end{array}$ & 1952 & Çiftçi & - & 14.11 .2010 & Çoban Dede & Merkez -Adiyaman \\
\hline 20 & Abuzer YALÇIN & 1950 & Çiftçi & - & 14.11 .2010 & Çoban Dede & Merkez -Adıyaman \\
\hline 21 & Hac1 DEMİRBAY & 1949 & Çiftçi & - & 14.11 .2010 & Çoban Dede & Merkez -Adıyaman \\
\hline 22 & $\begin{array}{l}\text { Yusuf } \\
\text { DEMIRBAY }\end{array}$ & 1948 & Çiftçi & - & 14.11 .2010 & Çoban Dede & Merkez-Adiyaman \\
\hline 23 & Yusuf ERGÜR & 1938 & Çiftçi & - & 15.12 .2010 & Koruk Köyü & Merkez-Elazığ \\
\hline 24 & Fikret ASLAN & 1949 & Çiftçi & - & 15.12 .2010 & Koruk Köyü & Merkez-Elazı̆̆ \\
\hline 25 & Sündüz ASLAN & 1947 & Ev Hanımı & - & 15.12 .2010 & Koruk Köyü & Merkez-Elazığ \\
\hline 26 & Zeki TAN & 1939 & Çiftçi & - & 16.12 .2010 & Sün Köyü & Merkez-Elazı̆̆ \\
\hline
\end{tabular}




\begin{tabular}{|c|c|c|c|c|c|c|c|}
\hline 27 & Hasan ÖNAY & 1933 & $\begin{array}{l}\text { Öğretmen } \\
\text { Emekli }\end{array}$ & - & 16.12 .2010 & Sün Köyü & Merkez-Elazığ \\
\hline 28 & Güllü ÖNAY & 1941 & Ev Hanımı & - & 17.12 .2010 & Sün Köyü & Merkez-Elazığ \\
\hline 29 & Cumaali GÖKSU & 1926 & Çiftçi & - & 17.12 .2010 & Sün Köyü & Merkez-Elazı̆̆ \\
\hline 30 & Makbule GÖKSU & 1935 & Ev Hanımı & - & 17.12 .2010 & Sün Köyü & Merkez-Elazığ \\
\hline 31 & Turan ÇALDAK & 1948 & Çiftçi & Şavak & 18.12 .2010 & Meşeli Köyü & Merkez-Elazığ \\
\hline 32 & Bekir GÖREN & 1957 & Çiftçi & Şavak & 19.12 .2010 & Salkaya Köyü & Merkez-Elazı̆̆ \\
\hline 33 & Sefer ALTUN & 1936 & Çiftçi & Şavak & 19.12 .2010 & Salkaya Köyü & Merkez-Elazığ \\
\hline 34 & Halil ÇALDAK & 1934 & Çiftçi & Şavak & 19.12 .2010 & Salkaya Köyü & Merkez-Elazı̆̆ \\
\hline 35 & $\begin{array}{l}\text { Metin Baki } \\
\text { ÖLÇÜCÜ }\end{array}$ & 1967 & Çiftçi & Beritan & 20.12 .2010 & - & Kovancilar-Elazığ \\
\hline 36 & $\begin{array}{l}\text { Mehmet Emin } \\
\text { AKDAĞ }\end{array}$ & 1963 & Çiftçi & Beritan & 20.12 .2010 & - & Kovancilar -Elazığ \\
\hline 37 & $\begin{array}{l}\text { Bekir BARAÇ } \\
\text { KILIÇ }\end{array}$ & 1969 & Çiftçi & Beritan & 20.12 .2010 & - & Kovancılar -Elazığ \\
\hline 38 & $\begin{array}{l}\text { Celal } \\
\text { DEMİRELLİ }\end{array}$ & 1959 & Çiftçi & Beritan & 20.12 .2010 & Yeni Dam Köyü & Kovancilar -Elazığ \\
\hline 39 & Ali ŞENER & 1955 & Çiftçi & Beritan & 21.12 .2010 & İğdeli Köyü & Kovancılar -Elazı̆̆ \\
\hline 40 & Nedim BULUT & 1950 & Kasap & - & 26.12 .2010 & Gevence Köyü & Nizip-Gaziantep \\
\hline 41 & Mehmet BULUT & 1951 & Esnaf & - & 26.12 .2010 & Gevence Köyü & Nizip-Gaziantep \\
\hline 42 & Radiya KESKİN & 1946 & Ev Hanımı & - & 27.12 .2010 & Sekile Köyü & Nizip-Gaziantep \\
\hline 43 & Musa KESKİN & 1985 & Çiftçi & - & 27.12 .2010 & Sekile Köyü & Nizip-Gaziantep \\
\hline 44 & $\begin{array}{l}\text { Mustafa } \\
\text { KANPOLAT }\end{array}$ & 1942 & Çiftçi & - & 28.12 .2010 & Söğütlü Köyü & Nizip-Gaziantep \\
\hline 45 & $\begin{array}{l}\text { Bilal } \\
\text { ALPARSLAN }\end{array}$ & 1929 & Çiftçi & - & 28.12 .2010 & Söğütlü Köyü & Nizip-Gaziantep \\
\hline 46 & $\begin{array}{l}\text { Mehmet } \\
\text { YÜKSEKAĞAÇ }\end{array}$ & 1963 & Vet. Hek. & - & 01.12 .2010 & - & Battalgazi-Malatya \\
\hline 47 & $\begin{array}{l}\text { Kemal } \\
\text { YEŞİLÇAYIR }\end{array}$ & 1968 & Vet. Hek. & - & 01.12 .2010 & - & Battalgazi-Malatya \\
\hline 48 & $\begin{array}{l}\text { Hüseyin } \\
\text { ERDEMİR }\end{array}$ & 1967 & Vet. Hek. & - & 01.12 .2010 & - & Battalgazi-Malatya \\
\hline 49 & Ramazan KOÇ & 1959 & Çiftçi & - & 01.12 .2010 & Karabağlar Köyü & Battalgazi-Malatya \\
\hline 50 & Hacı KALAY & 1943 & Çiftçi & - & 01.12 .2010 & Kıraç Köyü & Battalgazi-Malatya \\
\hline 51 & $\begin{array}{l}\text { Hasan } \\
\text { YİĞİTCAN }\end{array}$ & 1955 & Çiftçi & - & 02.12 .2010 & $\begin{array}{l}\text { Yenimahalle } \\
\text { Köyü }\end{array}$ & Battalgazi-Malatya \\
\hline 52 & Vahap ALTUN & 1955 & Çiftçi & - & 02.12 .2010 & $\begin{array}{l}\text { Yenimahalle } \\
\text { Köyü }\end{array}$ & Battalgazi-Malatya \\
\hline 53 & Mehmet AKBAŞ & 1950 & Çiftçi & - & 04.12 .2010 & $\begin{array}{l}\text { Günedoğru } \\
\text { Köyü }\end{array}$ & Doğanşehir-Malatya \\
\hline 54 & Hasan ÇUBUK & 1962 & Çiftçi & - & 04.12 .2010 & $\begin{array}{l}\text { Günedoğru } \\
\text { Köyü }\end{array}$ & Doğanşehir-Malatya \\
\hline 55 & Şahin EROL & 1948 & Çiftçi & - & 05.12 .2010 & Polat Beldesi & Doğanşehir-Malatya \\
\hline
\end{tabular}




\begin{tabular}{|c|c|c|c|c|c|c|c|}
\hline 56 & Hasan ÖZCAN & 1932 & Çiftçi & - & 07.12 .2010 & Söğüt Beldesi & Doğanşehir-Malatya \\
\hline 57 & Hacı ALTUNTAŞ & 1931 & Çiftçi & - & 07.12 .2010 & Söğüt Beldesi & Doğanşehir-Malatya \\
\hline 58 & Haydar GÜLER & 1937 & Çiftçi & - & 07.12 .2010 & Söğüt Beldesi & Doğanşehir-Malatya \\
\hline 59 & İbrahim MARAŞ & 1933 & Çiftçi & - & 07.12 .2010 & Söğüt Beldesi & Doğanşehir-Malatya \\
\hline 60 & Necmettin ATEŞ & 1953 & Çiftçi & - & 09.12 .2010 & $\begin{array}{l}\text { Kadir Uşağ1 } \\
\text { Köyü }\end{array}$ & Yeşilyurt-Malatya \\
\hline 61 & Aydın ARSLAN & 1961 & Çiftçi & - & 09.12 .2010 & $\begin{array}{l}\text { Kadir Uşağ1 } \\
\text { Köyü }\end{array}$ & Yeşilyurt-Malatya \\
\hline 62 & Ahmet GÜLMEZ & 1952 & Vet. Hek. & - & 22.10 .2010 & - & Merkez-Şanlıurfa \\
\hline 63 & Halil RUŞEN & 1969 & Vet. Hek. & - & 22.10 .2010 & - & Merkez-Şanlıurfa \\
\hline 64 & $\begin{array}{l}\text { Bahaddin } \\
\text { KARADAĞ }\end{array}$ & 1952 & Çiftçi & Getikan & 23.10 .2010 & Düzlüce Köyü & Birecik-Şanlıurfa \\
\hline 65 & Ramazan ÇOBAN & 1941 & Çiftçi & Şavak & 24.10 .2010 & Divrik Köyü & Birecik-Şanlıurfa \\
\hline 66 & Abdullah GÜNEŞ & 1937 & Çiftçi & Şavak & 24.10 .2010 & Divrik Köyü & Birecik-Şanlıurfa \\
\hline 67 & Mahmut DEMİR & 1955 & Çiftçi & Şavak & 24.10 .2010 & Unser Köyü & Birecik-Şanlıurfa \\
\hline 68 & Aziz DEMIR & 1966 & Çiftçi & Şavak & 24.10 .2010 & Unser Köyü & Birecik-Şanlıurfa \\
\hline 69 & $\begin{array}{l}\text { Mehmet } \\
\text { BİLENLER }\end{array}$ & 1950 & Çiftçi & - & 25.10 .2010 & Gözenek Köyü & Bozova-Şanlıurfa \\
\hline 70 & Şükrü BİLENLER & 1963 & Çiftçi & - & 25.10 .2010 & Gözenek Köyü & Bozova-Şanlıurfa \\
\hline 71 & Mehmet ÇELİK & 1943 & Çiftçi & - & 25.10 .2010 & $\begin{array}{l}\text { Türkmen veren } \\
\text { Köyü }\end{array}$ & Bozova-Şanlıurfa \\
\hline 72 & Güzel ŞAHİN & 1931 & Ev Hanımı & - & 26.10 .2010 & Arg1l Kasabası & Halfeti-Şanlıurfa \\
\hline 73 & $\begin{array}{l}\text { Mehmet Ali } \\
\text { ŞAHIN }\end{array}$ & 1943 & Çiftçi & - & 26.10 .2010 & Arg1l Kasabası & Halfeti-Şanlıurfa \\
\hline 74 & Haydar ŞAHİN & 1945 & Çiftçi & - & 26.10 .2010 & Arg1l Kasabası & Halfeti-Şanlıurfa \\
\hline 75 & Ayşe ŞAHİN & 1955 & Ev Hanımı & - & 27.10 .2010 & Arg1l Kasabası & Halfeti-Şanlıurfa \\
\hline 76 & $\begin{array}{l}\text { Recep } \\
\text { TEKINALP }\end{array}$ & 1946 & Çiftçi & $\begin{array}{l}\text { Beni } \\
\text { Muham } \\
\text { medi }\end{array}$ & 28.10 .2010 & Karatepe Köyü & Akçakale-Şanlıurfa \\
\hline 77 & Halil ÖZÇELİK & 1957 & Çiftçi & $\begin{array}{l}\text { Beni } \\
\text { Muham } \\
\text { medi }\end{array}$ & 28.10 .2010 & Karatepe Köyü & Akçakale-Şanliurfa \\
\hline 78 & Salih CAFIN & 1933 & Çiftçi & $\begin{array}{l}\text { Beni } \\
\text { Muham } \\
\text { medi }\end{array}$ & 29.10 .2010 & Doram Ali Köyü & Akçakale-Şanlıurfa \\
\hline
\end{tabular}

